\title{
Killer Cell Lectin-Like Receptor Subfamily G Member 1
}

National Cancer Institute

\section{Source}

National Cancer Institute. Killer Cell Lectin-Like Receptor Subfamily G Member 1. NCI

Thesaurus. Code C123855.

Killer cell lectin-like receptor subfamily G member 1 (195 aa, $\sim 22 \mathrm{kDa}$ ) is encoded by the human KLRG1 gene. This protein plays a role in immunomodulation. 